\title{
EVALUASI PEMANFAATAN PENGGUNAAN LAHANBERBASIS RENCANA POLA RUANG KOTA BAUBAU, PROVINSI SULAWESI TENGGARA
}

\author{
A Land Use Evaluation Of Baubau City, South East Sulawesi, Based \\ On The Urban Spatial Plan
}

\author{
Fikril Fahmi ${ }^{1}$, Santun R.P Sitorus ${ }^{2}$, Ahmad Fauzi $^{3}$
}

Diterima: 9 Oktober 2015 Disetujui: 26 Februari 2016

\begin{abstract}
Abstrak: $\quad$ Laju pertumbuhan ekonomi telah mendorong pembangunan Kota di berbagai sektor kehidupan. Hal ini berimplikasi terhadap peningkatan kebutuhan akan ruang. Perubahan penggunaan lahan yang begitu cepat terjadi tidak jarang menyimpang dari rencana pola ruang yang telah ditetapkan dalam RTRW. Penelitian ini bertujuan untuk mengevaluasi kesesuaian penggunaan lahan dan konsistensi rencana pola ruang dan mengetahui faktor yang mempengaruhi konsistensi penggunaan lahan pada rencana pola ruang. Analisis yang digunakan dalam penelitian ini menggunakan pendekatan SIG, Neraca Sumber Daya Lahan, Analisis Faktor dan Analisis Regresi Berganda. Berdasarkan hasil analisis, terdapat tiga bentuk inkonsistensi dalam rencana pola ruang Kota Baubau yakni inkonsisntensi dalam rencana pola ruang, inkonsistensi terhadap peraturan dan perundangan yang berlaku, dan inkonsistensi didalam pemanfaatan penggunaan lahan terhadap rencana pola ruang. Hasil evaluasi penggunaan lahan menunjukan bahwa tingkat kesesuaian penggunaan lahan terhadap rencana pola ruang berada pada konsistensi sedang. Adapun faktor yang mempengaruhi kesesuaian penggunaan lahan terhadap rencana pola ruang adalah kemudahan mencapai pusat-pusat layanan, peningkatan kesejahteraan, dan aksesibilitas.
\end{abstract}

\section{Kata Kunci: evaluasi, inkonsistensi, penggunaan lahan, rencana pola ruang}

Abstract: The high rate of economic growth has encouraged the development of Baubau City in various sectors of life. It has implications on the increase in space requirements. Rapid changes in land use often deviate from the spatial plan (RTRW) that has been legalized. This study aimed to evaluate the appropriateness and consistency of the land use plan and to investigate factors affecting the suitability and consistency of the land use growth with the spatial plan. The analysis has used GIS, Balance of Land Resources, Factor Analysis, and Multiple Regression Analysis. Based on the analysis, there are three forms of inconsistency from the spatial plan of Baubau, as follows: inconsistencies in the spatial plan itself, inconsistencies with the laws and regulations, and inconsistency in the utilization of the land use plan. The results have shown that the level of consistency to the land use plan is medium. The factors affecting the deviation of land use pattern from the plan are the ease of getting to service centers, the improved welfare, and the accessibility.

Keywords: evaluation, inconsistency, land use, spatial plan

1 Program Studi Ilmu Perencanaan Wilayah, Fakultas Pertanian, Institut Pertanian Bogor

2 Departemen Ilmu Tanah dan Sumberdaya Lahan, Fakultas Pertanian, Institut Pertanian Bogor

3 Departemen Ekonomi Sumberdaya dan Lingkungan, Fakultas Ekonomi dan Manajemen, Institut Pertanian Bogor

Korespondensi: fahmi.2413@gmail.com 


\section{PENDAHULUAN}

Lahan merupakan sumber daya pembangunan yang memiliki karakteristik unik, yakni (1) sediaan/luas relatif tetap karena perubahan luas akibat proses alami (sedimentasi) dan proses artifisial (reklamasi) sangat kecil; (2) memiliki sifat fisik (jenis batuan, kandungan mineral, topografi, dan sebagainya) dengan kesesuaian dalam menampung kegiatan masyarakat yang cenderung spesifik (Dardak, 2005). Segala macam bentuk intervensi manusia secara siklis dan permanen untuk memenuhi kebutuhannya, baik yang bersifat material maupun spiritual yang berasal dari lahan tercakup dalam pengertian pemanfaatan lahan. Hal serupa dinyatakan oleh Arsyad (2006).

Ruang/lahan akan selalu senantiasa berubah penggunaannya. Perubahan ini akan tetap berlanjut dimasa mendatang bahkan dalam kecepatan yang lebih tinggi seiring dengan pertumbuhan ekonomi yang dirasakan di kota-kota besar(Winarso, 1995).Oleh karena itu penggunaan lahan haruslah diatur didalam pemanfaatannya. Untuk mengatur penggunaan lahan, Pemerintah mengeluarkan aturan UURI No. 26 Tahun 2007 tentang Penataan Ruang(Sekretariat Negara, 2007) yang bertujuan untuk mewujudkan ruang wilayah nasional yang aman, nyaman, produktif, berkelanjutan berlandaskan Wawasan Nusantara dan Ketahanan Nasional dengan; a) terwujudnya keharmonisan antara lingkungan alam dan buatan, b) terwujudnya keterpaduan dalam penggunaan sumberdaya alam dan buatan dengan memperhatikan sumberdaya manusia, c)terwujudnya fungsi ruang dan pencegahan dampak negatif terhadap lingkungan akibat pemanfaatan ruang.

Pada implementasinya masih terjadi penyimpangan penggunaan lahan karena tidak konsisten terhadap Rencana Tata Ruang Wilayah (RTRW). Adapun terjadinya inkonsistensi tersebut dapat disebabkan oleh; (1) kekeliruan dalam penyusunan RTRW yang tidak mempertimbangkan faktor daya dukung dan daya tampung lahan menyangkut kesesuaian dan kelayakan lahannya, (2) Meningkatnya laju pertumbuhan ekonomi yang diikuti dengan peningkatan migrasi kependudukan sehingga memacu intensitas pemanfaatan lahan, (3) adanya investasi / penanaman modal sehingga Pemerintah Daerah dengan kekuasaan otonominya memberikan izin penggunaan lahan di luar koridor kawasan yang telah ditetapkan dalam Rencana Pola Ruang yang telah disepakati. Oleh karena itu dibutuhkan adanya evaluasi. Lahamendu \& Kustiwan(2014)menyatakan bahwa tujuan dari dilakukannya evaluasi adalah melakukan penilaian tentang pencapaian manfaat yang telah ditetapkan dalam rencana tata ruang, termasuk penemuan faktor-faktor yang menyebabkan pencapaian lebih dan/atau kurang dari manfaat yang telah ditetapkan dalam perencanaan tata ruang wilayah.

Kota Baubau yang terbentuk melalui UURI No. 13 Tahun 2001(Sekretariat Negara, 2001), sebagai salah satu kota yang ada di wilayah Provinsi Sulawesi Tenggara, Kota Baubau memiliki peran strategis dalam menggerakkan pembangunan daerah di Provinsi Sulawesi Tenggara, serta Indonesia Timur pada umumnya. Peran strategis tersebut antara lain sebagai berikut; (a) penghubung yang menghubungkan wilayah Indonesia Barat dengan wilayah Timur Indonesia melalui perhubungan laut, (b) sebagai terminal bahan bakar (Depot Pertamina) yang melayani kebutuhan bahan bakar untuk wilayah Indonesia Timur, (c) sebagai calon ibukota dari pemekaran wilayah Provinsi Sulawesi Tenggara Kepulauan. Karena potensi dan perannya yang strategis serta laju pertumbuhan ekonomi telah mendorong pembangunan Kota Baubau yang berimplikasi terhadap peningkatan kebutuhan akan ruang. Peningkatan kebutuhan ruang memicu proses perubahan penggunaan lahan yang cepat yang tidak jarang terjadi penyimpangan terhadap Rencana Pola Ruang.

Berdasarkan hal tersebut, maka tujuan dari penelitian ini adalah untuk mengevaluasi kesesuaian penggunaan lahan dan konsistensi Rencana Pola Ruang dan faktor-faktor yang mempengaruhi kesesuaian dan konsistensi dari penggunaan lahan terhadap Rencana Pola Ruang. 


\section{METODE PENELITIAN}

\section{Lokasi dan Waktu Penelitian}

Penelitian dilakukan di Kota Baubau,yang secara geografis terletak pada koordinat $5 \circ$

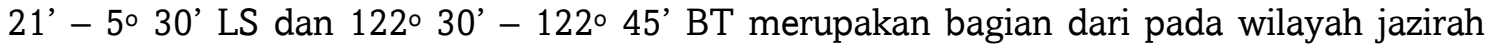
Sulawesi Tenggara bagian Selatan yang berada pada daratan Pulau Buton. Adapun batas wilayah dari Kota Baubau disebelah Utara berbatasan dengan Kecamatan Kapantori (Kabupaten Buton), sebelah Timur berbatasan dengan Kecamatan Pasar Wajo (Kabupaten Buton), sebelah Selatan berbatasan dengan Kecamatan Batauga, dan Selat Buton batas di sebelah Barat. Luas wilayah daratan Kota Baubau adalah 28.933,39 ha yang terbagi menjadi 8 kecamatan dan 43 kelurahan (Gambar 1). Penelitian dilakukan pada Bulan Maret-Juni 2015.

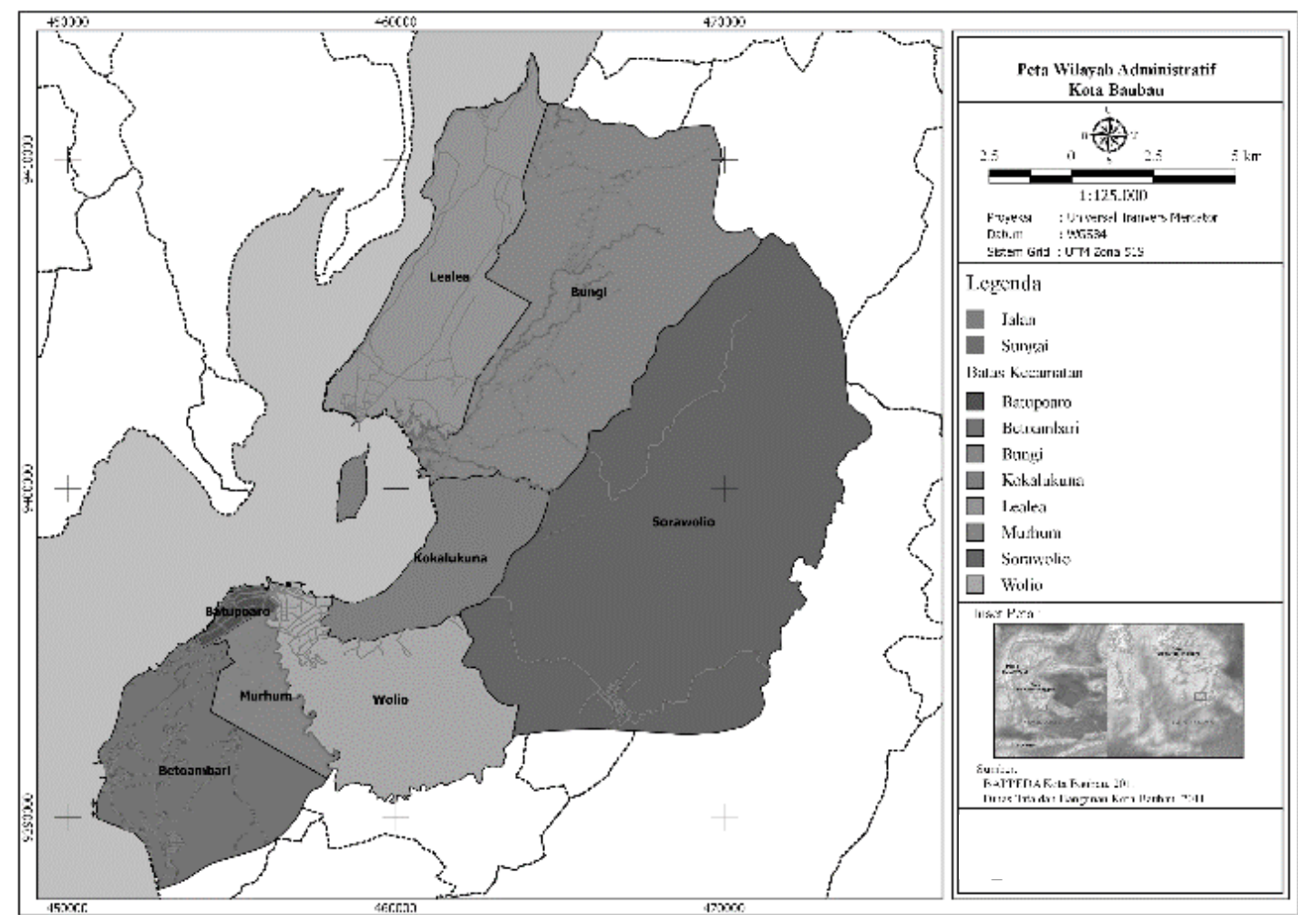

Gambar 1 Peta Administrasi Wilayah Kota Baubau

\section{Jenis Data dan Alat Penelitian}

Data yang digunakan dalam penelitian ini terdiri dari data primer dan data sekunder. Data primer diperoleh melalui pengamatan langsung dilapangan melalui wawancara, observasi, dan dokumentasi. Data sekunder meliputi dokumen RTRW Kota Baubau Tahun 2011-2031, Statistik Kota Baubau Tahun 2014, Potensi Desa Kota Baubau Tahun 2011, Peta Administrasi Kota Baubau, Peta Rencana Pola Ruang Kota Baubau Tahun 2011-2031, Citra Satelit Cnes/Astrium 2015 yang diperoleh dari instansi-instansi terkait dalam hal ini Bappeda Kota Baubau, BPS Kota Baubau dan Dinas Tata Ruang dan Tata Bangunan Kota Baubau. 
Alat yang digunakan untuk membantu mengolah data dalam penelitian ini adalah seperangkat computer dengan perangkat lunak antara lain QGIS 2.10, SAGA-GIS 2.1.2, Office, dan SPSS.

\section{Teknik Analisis Data}

Metode analisis yang digunakan dalam penelitian ini meliputi analisis spasial, analisis neraca sumberdaya lahan, analisis kesesuaian pemanfaatan penggunaan lahan, analisis faktor dengan metode komponen utama (Principal Component Analysis) dan analisis regresi berganda.

\section{Analisis Spasial}

Penelitian ini dilakukan dengan pendekatan geospasial yang memanfaatkan Sistem Informasi Geografis (SIG). Karakteristik utama dari SIG adalah kemampuan untuk menganalisis sistem seperti analisis statistik dan overlay yang disebut analisis spasial (Handayani, Soelistijasi, \& Sunardi, 2005). Lebih lanjut Handayani et al. (2005) menjelaskan bahwa analisis spasial tidak seperti sistem informasi yang lain karena memasukan dimensi ruang didalamnya. Kombinasi ini menggambarkan atribut-atribut pada bermacam fenomena seperti umur seseorang, tipe jalan, dan sebagainya yang secara bersama-sama dengan informasi seperti dimana seseorang tinggal atau lokasi suatu jalan. Teknik analisis spasial dilakukan dengan cara overlay. Overlay atau menumpang tindihkan peta merupakan salah satu fungsi dari SIG yang bertujuan untuk menghasilkan data spasial baru dari minimal dua data spasial yang menjadi masukkannya(Prahasta, 2002).

\section{Analisis Neraca Sumberdaya Lahan}

Neraca Sumber Daya Lahan (NSDL) adalah salah satu instrumen dalam evaluasi pemanfaatan penggunaan lahan suatu wilayah. Analisis NSDL sebagai salah satu bagian dari instrumen penataan ruang diatur penggunaanya dalam Undang-Undang Republik Indonesia Nomor 26 Tahun 2007 tentang Penataan Ruang Pasal 33 Ayat (1) dan (2). Adapun tata cara dan prosedur dalam proses penyusunan NSDL telah diatur dan telah terstandarisasi oleh Badan Standardisasi Nasional dengan nomor SNI 19-6728.2-2002 yakni tentang Penyusunan Neraca Sumberdaya, Bagian 3: Sumberdaya Lahan Spasial(Badan Standardisasi Nasional, 2002).

NSDL diartikan sebagai 'timbangan' dari aktiva dan pasiva sumberdaya lahan. NSDL disusun untuk mengetahui besarnya cadangan awal sumberdaya lahan yang dinyatakan dalam aktiva, dan besarnya pemanfaatan yang dinyatakan dalam pasiva, sehingga apabila terjadi perubahan cadangan dapat diketahui dengan besarnya sisa cadangan yang dinyatakan dengan saldo dalam untuk suatu wilayah dalam suatu kurun waktu (SNI 19-6728.2-2002). NSDL disajikan dalam bentuk model tabulasi statistik. berupa tabel skontro (sebelah menyebelah) seperti neraca keuangan. NSDL memperhitungkan degradasi sumberdaya lahan akibat pemanfaatan lahan yang diperhitungkan masuk dalam penggunaan lahan (pasiva). NSDL pada suatu daerah total luasannya tidak berubah tetapi hanya perubahan luasan fungsi dan nilai lahan. NSDL pun memperhitungkan pula nilai lahan dalam rupiah baik dalam aktiva maupun pasiva.

\section{Analisis Kesesuaian Pemanfaatan Penggunaan Lahan}

Analisis kesesuaian pemanfaatan penggunaan lahan bertujuan untuk mengevaluasi sejauhmana konsistensi dalam pelaksanaan RTRW atau sejauhmana kesesuaian pemanfaatan penggunaan lahan terhadap Rencana Pola Ruang yang telah ditetapkan dalam RTRW (Ditjen Penataan Ruang Kementerian PU, 2010). Untuk membantu proses 
analisis ini digunakan matriks NSDL dan hasil analisis spasial pada analisis sebelumnya sebagai instrumen pembantu. Hasil daripada analisis spasial dan matriks NSDL, berupa luasan-luasan penggunaan lahan yang menyimpang/tidak sesuai dengan rencana pola ruang, kemudian diterjemahkan ke dalam rentang nilai kualitatif dari rendah hingga tinggi. Selanjutnya nilai kualitatif ini dibuat dalam nilai kuantitatif dengan skala 4 (nilai 0 sampai dengan 4), dimana 0 menunjukan angka terendah yang berarti telah terjadi ketidaksesuaian / tidak sesuai sama sekali dan angka 4 menunjukan angka tertinggi yang berarti telah sesuai. Adapun klasifikasi nilai sebagaimana berikut:
- $>99 \%$
: Tidak ada kesesusuaian dengan nilai 0
- $50 \%-<99 \%$
: Simpangan tinggi dengan nilai 1
- $25 \%-<50 \%$
: Simpangan sedang dengan nilai 2
- $1 \%-<25 \%$
: Simpangan rendah dengan nilai 3
- $0 \%-<1 \%$
: Kesesuaian sempurna dengan nilai 4

Setelah masing-masing kelas pemanfaatan lahan dilakukan penilaian maka selanjutnya adalah mengkategorikan tingkat ketidaksesuaian/inkonsistensi dari penggunaan lahan terhadap Rencana Pola Ruang. Tingkat ketidaksesuaian/inkonsistensi penggunaan lahan dikelompokan menjadi tiga kategori yakni tingkat inkonsistensi rendah, tingkat inkonsistensi sedang, dan tingkat inkonsistensi tinggi dengan nilai dari masingmasing kategori adalah sebagai berikut:
- $\quad$ Tingkat Inkonsistensi Rendah
$: 0 \%-25 \%$
- Tingkat Inkonsistensi Sedang
$: 25 \%-50 \%$
- Tingkat Inkonsistensi Tinggi
: $50 \%-100 \%$

\section{Analisis Faktor}

Analisis faktor dengan metode komponen utama (Principal Component Analysis) merupakan metode statistic multivariate yang bertujuan untuk memperkecil dimensi peubah asal sehingga diperoleh peubah baru (komponen utama) yang tidak saling berkorelasi tetapi menyimpan sebagian besar informasi yang terkandung dalam peubah asal(Adiningsih \& Mahmud, 2004). Dalam penelitian ini analisis komponen utama digunakan untuk mengetahui faktor-faktor yang mempengaruhi perubahan penggunaan lahan dan konsistensinya terhadap Rencana Pola Ruang.

\section{Analisis Regresi Berganda}

Gujarati(2006) mendefinisikan analisis regresi sebagai kajian terhadap hubungan satu variabel yang disebut sebagai variabel yang diterangkan(the explained variabel) dengan satu atau dua variabel yang menerangkan (the explanatory). Variabel pertama disebut juga sebaga variabel tergantung dan variabel kedua disebut juga sebagai variabel bebas. Jika variabel bebas lebih dari satu, maka analisis regresi disebut regresi linear berganda. Disebut berganda karena pengaruh beberapa variabel bebas yang akan dikenakan kepada variabel tergantung. Tujuan dari analisis regresi dalam penelitian ini adalah untuk mengetahui keeratan hubungan faktor-faktor penduga yang terbentuk dari analisis faktor sebelumnya yang menyebabakan terjadinya perubahan dan peyimpangan-penyimpangan penggunaan dalam pemanfaatan ruang. Adapun yang menjadi variabel tergantung (y) adalah luas perubahan/penyimpangan dari pemanfataan penggunaan lahan yang diperoleh dari Analisis Spasial, sedangkan variabel-variabel bebas (x) adalah merupakan komponen utama yang terbentuk hasil dari pada analisis faktor. 


\section{HASIL DAN PEMBAHASAN}

\section{Evaluasi Kesesuaian Penggunaan Lahan Tahun 2015 Terhadap Rencana Pola Ruang RTRW Kota Baubau Tahun 2011-2031}

Berdasarkan UURI No. 26 Tahun 2007 tentang Penataan Ruang telah dijelaskan bahwa kegiatan penataan ruang merupakan rangkaian proses yang terdirit dari kegiatan perencanaan, pemanfaatan ruang, dan pengendalian pemanfaatan ruang. Dalam proses pengendalian pemanfaatan ruang maka dibutuhkan adanya evaluasi untuk menilai sejauhmana Rencana Pola Ruang telah diterapkan. Adapun proses evaluasi ini dilakukan melalui pendekatan spasial menggunakan teknik overlay yang kemudian disajikan dalam matriks Neraca Sumber Daya Lahan (NSDL). Penggunaan NSDL telah dalam proses penataan ruang telah diatur didalam UURI No. 26 Tahun 2007 pasal 33 ayat (1) dan (2) yang penggunaanya telah terstandardisasi dengan nomor SNI 19-6728.2-2002. NSDL diartikan sebagai timbangan dari aktiva dan pasiva sumberdaya lahan. Adapun yang menjadi aktiva dalam matriks ini adalah Rencana Pola Ruang RTRW Tahun 2011-2031 dan yang menjadi pasiva adalah penggunaan lahan kota Baubau Tahun 2015. Adapun hasil analisis dapat dilihat pada Tabel 1 dan Tabel 2.

Berdasarkan Tabel 1 terdapat perbedaan luasan jumlah antara kolom aktiva dan pasiva sebesar 35,7 ha. Terlihat bahwa Pemerintah Daerah berencana melakukan perluasan dataran Kota Baubau. Hal ini dilakukan dengan melakukan proses reklamasi pantai. Dari tahun 2010-2015 tercatat bahwa Pemda Kota Baubau telah melakukan reklamasi 26,6 ha. Proses reklamasi yang telah berlangsung ini telah mengakibatkan kerusakan lingkungan estuaria / perairan sekitar (Faizu, 2011).

Dari Tabel 1 dapat dilihat bahwa terdapat bentuk inkonsistensi dalam Rencana Pola Ruang Kota Baubau Tahun 2011-2031 yang melanggar undang-undang. Adapun bentuk inkonsistensi tersebut; (1) Rencana Pola Ruang menghilangkan kawasan Hutan Suaka Alam Wisata (HSAW) Tirta Rimba dalam peruntukan penggunaan lahan dan mengalihfungsikan kawasan tersebut menjadi kawasan pergudangan(lihat Tabel 2). HSAW dalam UURI No 26 Tahun 2007 dikategorikan sebagai kawasan lindung. (2) Pemda Kota Baubau berencana mengalihfungsikan kawasan mangrove seluas 70,9 ha menjadi peruntukan lain (lihat Tabel 2). Kawasan mangrove juga merupakan salah satu kawasan yang dilindungi keberadaannya. (3) Pemda Kota Baubau berencana mengurangi jumlah kawasan persawahan dan menjadikannya peruntukan lain (lihat Tabel 2).Luasperuntukan sawah dalam Rencana Pola Ruang sebesar 353,5 ha sedangkan luasan sawah eksisting sebesar 1.274,9 ha. maka demikian Rencana Pola Ruang yang disusun telah melanggar UURI No. 41 Tahun 2009 tentang Perlindungan Lahan Pertanian Pangan Berkelanjutan (Sekretariat Negara, 2009)yang mengharuskan dilindunginya kawasan dan lahan pertanian guna mewujudkan kemandirian, ketahanan dan kedaulatan pangan.

Bentuk-bentuk penyimpangan penggunaan dapat dilihat pada Tabel 2. Berdasarkan Tabel 2, Luasan kawasan hutan lindung di Kota Baubau jauh lebih besar dibandingkan dengan luasan yang direncanakan didalam Rencana Pola Ruang, dimana luas kawasan hutan lindung sebesar 4,471.9 ha sedangkan luasan didalam rencana Pola Ruang adalah sebesar 4,363.7 ha. Dari total luasan kawasan hutan lindung (4,471.9 ha) sebesar 4,241.8 ha sesuai fungsinya sebagai hutan lindung dan sisanya sebesar 230.1 ha dialihkan penggunaannya oleh Pemerintah Daerah menjadi Hutan Produksi (35.4 ha), Hutan Produksi Terbatas (22.0 ha), Pertanian Lahan Kering (17.4 ha), Pertambangan (150.5 ha), dan Kawasan Perdagangan dan jasa (4.8 ha). Berdasarkan Rencana Pola Ruang, Kawasan Hutan Lindung memiliki luasan 4,363.7 ha dan berdasarkan penggunaan lahan luasan hutan lindung adalah sebesar 4,241.8 ha, maka demikian terjadi penyalahgunaan lahan sebesar 121.9 ha berupa penggunaan lahan permukiman (0.3 ha), sawah (0.1 ha), Pertanian Lahan Kering (121.5 ha) dan Pertambangan (0.1 ha) 
Tabel 1 Matriks NSDL Kota Baubau Tahun 2015

\begin{tabular}{|c|c|c|c|c|c|c|c|}
\hline \multirow{3}{*}{ No } & \multicolumn{3}{|c|}{$\begin{array}{l}\text { Rencana Pola Ruang Tahun 2011-2031 } \\
\text { (Aktiva) }\end{array}$} & \multicolumn{4}{|c|}{$\begin{array}{l}\text { Penggunaan Lahan Tahun } 2015 \\
\text { (Pasiva) }\end{array}$} \\
\hline & \multirow{2}{*}{ Rencana Pola Ruang } & \multicolumn{2}{|c|}{ Luas } & \multirow{2}{*}{ No } & \multirow{2}{*}{ Rencana Pola Ruang } & \multicolumn{2}{|c|}{ Luas } \\
\hline & & ha & $\%$ & & & ha & $\%$ \\
\hline I & Kawasan Lindung & & & I & Kawasan Lindung & & \\
\hline \multirow[t]{2}{*}{1} & Hutan Lindung & $4,399.6$ & 15.2 & 1 & Hutan Lindung & $4,471.9$ & 15.4 \\
\hline & & & & 2 & HSAW Tirta Rimba & 466.2 & 1.6 \\
\hline 2 & Hutan Kota & 391.7 & 1.3 & 3 & Hutan Kota & 339.9 & 1.2 \\
\hline \multirow[t]{2}{*}{3} & Hutan Raya & 177.7 & 0.6 & 4 & Hutan Raya & 108.9 & 0.4 \\
\hline & & & & 5 & Kawasan Mangrove & 70.9 & 0.2 \\
\hline 4 & Kawasan Cagar Budaya & 87.4 & 0.3 & 6 & Kawasan Cagar Budaya & 28.7 & 0.1 \\
\hline 5 & Konservasi Pantai & 62.8 & 0.2 & 7 & Konservasi Pantai & 36.3 & 0.1 \\
\hline II & Kawasan Budidaya & & & II & Kawasan Budidaya & & \\
\hline 1 & Hutan Produksi & $1,347.7$ & 4.6 & 1 & Hutan Produksi & $1,275.8$ & 4.4 \\
\hline 2 & Hutan Produksi Terbatas & $3,826.4$ & 13.2 & 2 & Hutan Produksi Terbatas & $4,971.1$ & 17.2 \\
\hline \multirow[t]{5}{*}{3} & Permukiman & & & 3 & Permukiman & & \\
\hline & Permukiman & $3,412.0$ & 11.8 & & Permukiman & $3,338.1$ & 11.5 \\
\hline & Taman & 128.2 & 0.4 & & Taman & 125.8 & 0.4 \\
\hline & Fasilitas Sosial & 11.8 & 0.0 & & Fasilitas Sosial & 11.6 & 0.0 \\
\hline & Fasilitas Umum & 557.3 & 1.9 & & Fasilitas Umum & 493.8 & 1.7 \\
\hline 4 & Sawah & 353.5 & 1.2 & 4 & Sawah & $1,274.9$ & 4.4 \\
\hline 5 & Pertanian Lahan Kering & $5,792.7$ & 20.0 & 5 & Pertanian Lahan Kering & $5,666.5$ & 19.6 \\
\hline \multirow[t]{3}{*}{6} & Kawasan pertambangan & & & 6 & Kawasan pertambangan & & \\
\hline & Pertambangan Nikel & $1,795.7$ & 6.2 & & Pertambangan Nikel & 569.8 & 2.0 \\
\hline & Pertambangan & $2,922.3$ & 10.1 & & Pertambangan & $2,922.3$ & 10.1 \\
\hline 7 & Industri Perikanan & 11.2 & 0.0 & 7 & Industri Perikanan & 5.5 & 0.0 \\
\hline 8 & Wisata Pantai & 149.2 & 0.5 & 8 & Wisata Pantai & 108.0 & 0.4 \\
\hline \multirow[t]{4}{*}{9} & Perhubungan & & & 9 & Perhubungan & & \\
\hline & Kawasan Bandara & 217.9 & 0.8 & & Kawasan Bandara & 213.0 & 0.7 \\
\hline & Kawasan Pelabuhan & 140.9 & 0.5 & & Kawasan Pelabuhan & 90.0 & 0.3 \\
\hline & & & & & Kawasan Terminal & 10.8 & 0.0 \\
\hline \multirow[t]{13}{*}{10} & Lain-lain & & & 10 & Lain-lain & & \\
\hline & Perkantoran & $1,085.7$ & 3.7 & & Perkantoran & $1,007.1$ & 3.5 \\
\hline & $\begin{array}{l}\text { Perdagangan dan } \\
\text { Jasa }\end{array}$ & $1,451.5$ & 5.0 & & $\begin{array}{l}\text { Perdagangan dan } \\
\text { Jasa }\end{array}$ & 976.9 & 3.4 \\
\hline & Pergudangan & 352.4 & 1.2 & & Pergudangan & 16.6 & 0.1 \\
\hline & Kawasan Khusus & & & & Kawasan Khusus & & \\
\hline & Pertamina & 61.6 & 0.2 & & Pertamina & 59.8 & 0.2 \\
\hline & $\begin{array}{l}\text { Kawasan Pertahanan } \\
\text { Dan Keamanan }\end{array}$ & 155.8 & 0.5 & & Kawasan Pertahanan & 155.8 & 0.5 \\
\hline & TPA & 13.2 & 0.0 & & TPA & 13.2 & 0.0 \\
\hline & PLTU & 109.7 & 0.4 & & PLTU & 109.7 & 0.4 \\
\hline & & & & & Tambak & 41.4 & 0.1 \\
\hline & & & & & Luas Lahan Berubah & $2,727.7$ & \\
\hline & Total Keadaan Awal & 29,016 & & & Luas Lahan Tidak Berubah & $26,252.6$ & \\
\hline & Total Luas Daerah & 29,016 & & & Luas Total Daerah & $28,980.4$ & \\
\hline
\end{tabular}

Sumber : Data Diolah (2015)

Kawasan HSAW Tirta Rimba, sebagaimana telah dijelaskan sebelumnya bahwa merupakan bentuk inkonsistensi didalam penyusunan Rencana Pola Ruang karena tidak tercantum di dalam Rencana Pola Ruang. Adapun pengalihan kawasan HSAW seluas 467.0 ha menjadi kawasan Hutan Produksi (86.7ha), Hutan Produksi Terbatas (33.0 ha), Permukiman (14.7 ha), Wisata Pantai (6.2 ha), Kawasan Pelabuhan (25.8 ha), dan Kawasan Pergudangan (297.7 ha). Pada kawasan peruntukan Hutan Kota (393.0 ha), terdapat penyimpangan penggunaan lahan berupa kawasan permukiman (7.6 ha), Sawah (9.6 ha) dan aktivitas Pertanian Lahan Kering (35.8 ha). 
Tabel 2 Matriks Penyimpangan Penggunaan Lahan Tahun 2015 Terhadap Rencana Pola Ruang Kota Baubau Tahun 2011-2031

\begin{tabular}{|c|c|c|c|c|c|}
\hline \multirow{3}{*}{ No } & \multirow{3}{*}{$\begin{array}{l}\text { Rencana Pola Ruang 2011- } \\
2031\end{array}$} & \multicolumn{4}{|c|}{ Alih Fungsi /Konversi } \\
\hline & & \multicolumn{2}{|c|}{ Penambahan } & \multicolumn{2}{|l|}{ Pengurangan } \\
\hline & & Sumber Penambahan & ha & Bentuk Pengurangan & ha \\
\hline I & Kawasan Lindung & & & & \\
\hline \multirow[t]{5}{*}{1} & Hutan Lindung & Hutan Produksi & 35.4 & Permukiman & 0.3 \\
\hline & & Hutan Produksi Terbatas & 22.0 & Sawah & 0.1 \\
\hline & & Pertanian Lahan Kering & 17.4 & Pertanian Lahan Kering & 121.5 \\
\hline & & Pertambangan & 150.5 & Pertambangan & 0.1 \\
\hline & & Perdagangan dan Jasa & 4.8 & & \\
\hline \multirow[t]{6}{*}{2} & HSAW Tirta Rimba & Hutan Produksi & 86.7 & & \\
\hline & & Hutan Produksi Terbatas & 33.1 & & \\
\hline & & Permukiman & 17.5 & & \\
\hline & & Wisata Pantai & 6.2 & & \\
\hline & & Pelabuhan & 25.8 & & \\
\hline & & Pergudangan & 297.7 & & \\
\hline \multirow[t]{3}{*}{3} & Hutan Kota & & & Permukiman & 7.6 \\
\hline & & & & Sawah & 9.6 \\
\hline & & & & Pertanian Lahan Kering & 35.8 \\
\hline 4 & Hutan Raya & & & Pertanian Lahan Kering & 69.0 \\
\hline \multirow[t]{5}{*}{5} & Kawasan Mangrove & Permukiman & 14.8 & & \\
\hline & & Fasilitas Sosial & 0.2 & & \\
\hline & & Sawah & 2.3 & & \\
\hline & & Pertanian lahan Kering & 32.6 & & \\
\hline & & Wisata Pantai & 21 & & \\
\hline 6 & Kawasan Cagar Budaya & & & Pertanian Lahan Kering & 50.6 \\
\hline \multirow[t]{3}{*}{7} & Konservasi Pantai & & & Permukiman & 2.7 \\
\hline & & & & Pertanian Lahan Kering & 16.9 \\
\hline & & & & Tambak & 6.8 \\
\hline II & Kawasan Budidaya & & & & \\
\hline \multirow[t]{6}{*}{1} & Hutan Produksi & Permukiman & 67.7 & Pertanian Lahan Kering & 710.5 \\
\hline & & Fasilitas Umum & 45.2 & & \\
\hline & & Pertanian Lahan Kering & 245.3 & & \\
\hline & & Perkantoran & 63.0 & & \\
\hline & & Perdagangan dan Jasa & 178.4 & & \\
\hline & & Pergudangan & 11.7 & & \\
\hline \multirow[t]{3}{*}{2} & Hutan Produksi Terbatas & Permukiman & 16.2 & Sawah & 15.0 \\
\hline & & Pertanian Lahan Kering & 238.6 & Pertanian Lahan Kering & 203.7 \\
\hline & & Pertambangan & $\begin{array}{r}1,233 \\
0\end{array}$ & Pertambangan & 64.5 \\
\hline \multirow[t]{6}{*}{3} & Permukiman & Sawah & 153.9 & Pelabuhan & 0.9 \\
\hline & & Perkantoran & 124.9 & TPA & 2.5 \\
\hline & & Perdagangan dan Jasa & 118.9 & Bandara & 4.8 \\
\hline & & Pergudangan & 2.6 & & \\
\hline & & Kawasan & 1.8 & & \\
\hline & & Pelabuhan Pertamina & & & \\
\hline 4 & Fasilitas Umum & Sawah & 18.6 & & \\
\hline 5 & Taman & & & Wisata Pantai & 0.2 \\
\hline \multirow[t]{2}{*}{6} & Sawah & Pertanian Lahan Kering & 516.1 & & \\
\hline & & Perdagangan dan Jasa & 212.9 & & \\
\hline \multirow[t]{2}{*}{7} & Pertanian Lahan Kering & & & Wisata Pantai & 2.9 \\
\hline & & & & Pelabuhan & 0.3 \\
\hline \multirow[t]{2}{*}{8} & Wisata Pantai & Pelabuhan & 0.3 & & \\
\hline & & Perdagangan dan Jasa & 0.7 & & \\
\hline 9 & Pelabuhan & Perdagangan dan Jasa & 2.0 & & \\
\hline
\end{tabular}

Sumber : Data diolah (2015)

Pada Peruntukan kawasan Hutan Raya terdapat penyimpangan penggunaan lahan berupa Pertanian Lahan Kering seluas 68.9 ha.Kawasan Mangrove merupakan salah satu bentuk ketidakkonsistenan Rencana Pola Ruang yang disusun oleh Pemerintah Daerah. 
Sebagaimana telah dijelaskan sebelumnya bahwa terdapat luasan mangrove sebesar 70.9 ha yang berpotensi berubah fungsinya. Adapun perubahan fungsi kawasan mangrove diarahkan menjadi kawasan permukiman (14.8 ha) dan fasilitas sosial (0.2 ha), sawah (2.3 ha) Pertanian Lahan kering (32.6) ha, Wisata Pantai (21.0 ha).

Kawasan Cagar Budaya yang ada di Kota Baubau adalah merupakan kawasan Benteng Keraton Buton. Dalam Rencana Pola Ruang dari luasan yang diperuntukan sebagai kawasan cagar budaya, Kawasan Benteng Keraton Buton mengambil luasan sebesar 28.7 ha dan sisanya adalah merupakan kawasan Pertanian Lahan Kering sebesar 50.6 ha yang keberadaannya berada di luar kawasan Benteng Keraton Buton. Pada peruntukan kawasan Konservasi Pantai terdapat penyalahgunaan lahan berupa permukiman (2.7 ha), pertanian lahan kering (16.9 ha), dan tambak (6.8 ha).

Pada peruntukan Kawasan Hutan Produksi ditemukan aktivitas Pertanian Lahan Kering sebesar 710.5 ha. Dari total luasan kawasan Hutan Produksi (1,275.8 ha) oleh Pemerintah Daerah dalam Rencana Pola Ruang direncanakan dialihfungsikan menjadi kawasan permukiman (67.7 ha), Fasilitas Umum (45.2 ha), Pertanian Lahan Kering (245.3 ha), Perkantoran (62.9 ha), Perdagangan dan Jasa (178.4 ha), Pergudangan (11.7ha). Pada peruntukan Kawasan Hutan Produksi Terbatas ditemukan adanya penyimpangan penggunaan lahan berupa Sawah (15.0 ha), Pertanian Lahan Kering (203.7 ha) dan Pertambangan (64.5 ha). Dari total luasan Hutan Produksi Terbatas (4,971.1ha) oleh Pemerintah Daerah dalam Rencana Pola Ruang direncanakan untuk dialihfungsikan menjadi peruntukan Permukiman (16.2 ha), Pertanian Lahan Pertanian Lahan Kering (238.6 ha) dan Pertambangan (1,232.9 ha).

Pada peruntukan kawasan Permukiman ditemukan adanya penyimpangan penggunaan lahan berupa kawasan Sawah sebesar 153.9 ha. kawasan Sawah dalam peruntukan penggunaan lahan permukiman karena ketidakkonsistenan Rencana Pola Ruang sebagaimana telah dijelaskan sebelumnya. Selain itu penyimpangan penggunaan lahan lainnya berupa kawasan pelabuhan (0.9 ha), TPA (2.5 ha), Perkantoran (124.9 Ha), Perdagangan dan Jasa (118.9 ha), Pergudangan (2.6 ha).Kawasan peruntukan Sawah, sebagaimana telah dijelaskan sebelumnya bahwa merupakan bentuk inkonsistensi dalam Rencana Pola Ruang, dimana luas yang direncanakan dalam pola ruang seluas 353.5 ha, sedangkan luasan sawah di Kota Baubau adalah sebesar 1,274.9 ha. Maka demikian keberadaan sawah diluar dari Rencana Pola Ruang menjadi suatu bentuk penyimpangan karena letaknya diluar dari Rencana Pola Ruang. Adapun lokasi-lokasi keberadaan sawah di luar peruntukannya di dalam Rencana Pola Ruang terdapat pada peruntukan kawasan Hutan Lindung (0.3 ha), Hutan Kota (7.6 ha), Hutan Produksi Terbatas (15.0 ha), Permukiman (152.6 ha), Fasilitas Umum (18.6 ha), Pertanian Lahan Kering (516.1 ha), Perdagangan dan Jasa (212.9 ha).Pada peruntukan Kawasan Bandara terdapat penyimpangan penggunaan lahan berupa kawasan permukiman seluas 4.8 ha.

Berdasarkan hasil evaluasi pemanfaatan penggunaan lahan Kota Baubau tahun 2015 terhadap Rencana Pola Ruang maka didapatkan hasil bahwa tingkat inkonsistensi pelaksanaan Rencana Pola Ruang berada pada tingkat sedang dimana luas penyimpangan yang terjadi pada Kota Baubau berada pada rentang nilai $25 \%-50 \%$. Adapun sebaran wilayah penyimpangan penggunaan lahan yang terjadi di Kota Baubau dapat dilihat pada gambar 2 . 


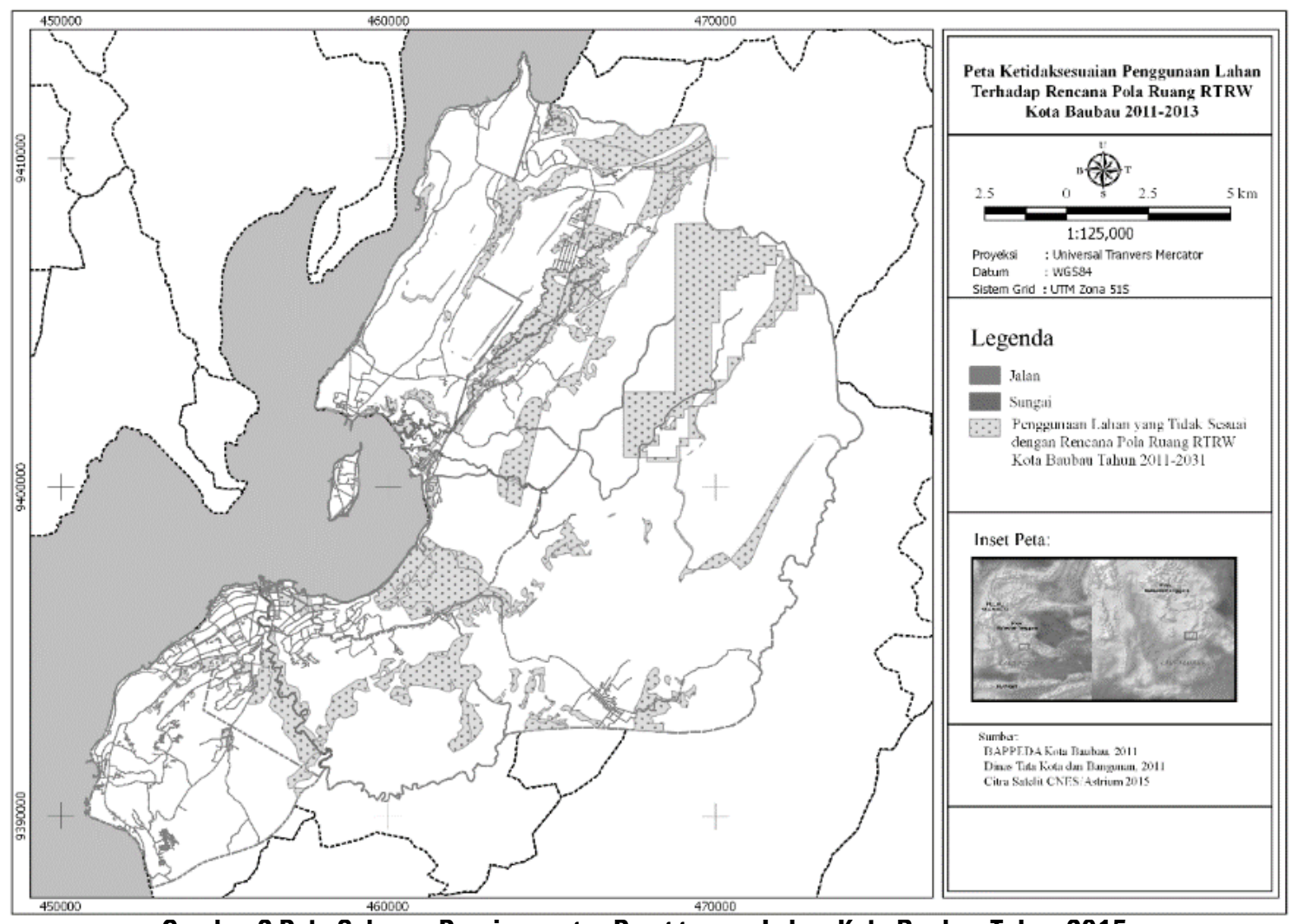

Gambar 2 Peta Sebaran Penyimpangan Penggunaan Lahan Kota Baubau Tahun 2015

\section{Faktor-faktor yang Mempengaruhi Kesesuaian penggunaan Lahan Terhadap Rencana Pola Ruang RTRW Kota Baubau 2011-2031}

Dalam menentukan faktor-faktor yang diduga mempengaruhi tingkat kesesuaian penggunaan lahan terhadap Rencana Pola Ruang digunakan data Potensi Desa Kota Baubau dan Statistik Kota Baubau serta penggunaan lahan sebagai variabel penduga sebagaimana dapat dilihat pada Tabel 3. Variabel-variabel tersebut kemudian dianalisis menggunakan analisis faktor dengan metode komponen utama (Principal Componene Analysis) menggunakan software SPSS. Analisis faktor digunakan untuk menemukan hubungan antar sejumlah variabel-variabel yang saling bebas antar satu dengan yang lain sehingga bisa dibuat satu atau beberapa kumpulan variabel yang lebih sedikit dari jumlah variabel awal(Santoso, 2006). Santoso (2006) menerangkan lebih lanjut dalam melakukan analisis faktor sejumlah asumsi berikut harus dipenuhi: (1) Korelasi antarvariabel indpenden, dimana korelasi antar variabel independen harus cukup kuat, misalnya diatas 0.5 . (2) Korelasi Parsial, merupakan korelasi antar dua variabel dengan menganggap tetap variabel yang lain haruslah kecil. Pada SPSS deteksi terhadap korelasi parsial diberikan lewat pilihan Anti Image Correlation. (3) Pengujian seluruh matriks korelasi (korelasi antar variabel), yang diukur dengan besaran Bartlett Test of Sphericity atau Measure Sampling Adequacy (MSA). Pengujian ini mengharuskan adanya korelasi yang signifikan diantara paling sedikit beberapa variabel, (4) Pada beberapa kasus, asumsi normalitas dari variabelvariabel atau faktor yang terjadi sebaiknya dipenuhi.

Berdasarkan uji KMO dan Bartlett yang digunakan untuk menilai kelayakan variabel yang digunakan dalam analisis faktor, variabel-variabel yang tertera pada Tabel 3 layak dan dapat digunakan dalam analisis faktor. Adapun faktor-faktor baru yang terbentuk yang mempengaruhi kesesuaian penggunaan lahan dapat dilihat pada Tabel 4. 
Tabel 3 Variabel Penduga Yang Mempengaruhi Kesesuaian Penggunaan Lahan Terhadap Rencana Pola Ruang RTRW Kota Baubau

\begin{tabular}{cl}
\hline No & Variabel Penduga \\
\hline 1 & Luas Wilayah \\
2 & Jumlah Penduduk \\
3 & Kepadatan Penduduk \\
4 & Jarak Ke Pusat Kecamatan \\
5 & Jarak Ke Pusat Kota \\
6 & Rasio Keluarga Pertanian \\
7 & Rasio Keluarga Pra Sejahtera \\
8 & Rasio Keluarga Sejahtera III \\
9 & Rasio Luas Sawah \\
10 & Rasio Luas Sawah dengan Pengairan yang Diusahakan \\
11 & Rasio Luas Pertanian Lahan Kering \\
12 & Jarak Ke Pusat Perdagangan \\
13 & Jarak Ke Pusat Layanan Pendidikan \\
14 & Jarak Ke Pusat Layanan Kesehatan \\
15 & Pertambahan Panjang Ruas Jalan \\
16 & Laju Pertambahan Panjang Ruas Jalan \\
\hline
\end{tabular}

Sumber: Data Diolah (2015)

Tabel 4 Faktor yang terbentuk berdasarkan hasil analisis faktor komponen utama

\begin{tabular}{lrrr}
\hline \multirow{2}{*}{ Variabel } & \multicolumn{3}{c}{ Component } \\
\cline { 2 - 4 } & \multicolumn{1}{c}{$\mathbf{1}$} & \multicolumn{1}{c}{$\mathbf{2}$} & \multicolumn{1}{c}{$\mathbf{3}$} \\
\hline Luas Wilayah & $\mathbf{0 . 5 9 9}$ & 0.146 & 0.271 \\
Jumlah Penduduk & -0.582 & -0.133 & -0.270 \\
Kepadatan Penduduk & -0.595 & -0.085 & -0.512 \\
Jarak ke Pusat Kecamatan & $\mathbf{0 . 5 1 0}$ & 0.004 & 0.086 \\
Jarak ke Pusat Kota & $\mathbf{0 . 9 0 8}$ & 0.262 & 0.209 \\
Rasio Keluarga Pertanian & $\mathbf{0 . 8 9 8}$ & 0.105 & 0.113 \\
Rasio Keluarga Pra Sejahtera & $\mathbf{0 . 7 0 7}$ & -0.278 & 0.139 \\
Rasio Keluarga Sejahtera III & -0.346 & $\mathbf{0 . 6 8 4}$ & -0.092 \\
Rasio Luas Sawah & 0.387 & $\mathbf{0 . 8 4 8}$ & 0.070 \\
Rasio Luas Sawah dengan Pengairan yang diusahakan & 0.372 & $\mathbf{0 . 8 5 3}$ & 0.068 \\
Rasio Luas Pertanian Lahan Kering & $\mathbf{0 . 6 9 4}$ & -0.139 & 0.106 \\
Jarak ke pusat perdagangan terdekat & $\mathbf{0 . 9 0 9}$ & 0.268 & 0.207 \\
Jarak ke pusat pelayanan pendidikan terdekat & $\mathbf{0 . 9 1 5}$ & 0.291 & 0.115 \\
Jarak ke Pusat Pelayanan Kesehatan terdekat & $\mathbf{0 . 9 1 2}$ & 0.276 & 0.164 \\
Pertumbuhan Ruas Jalan & 0.189 & 0.096 & $\mathbf{0 . 8 7 4}$ \\
Laju pertumbuhan ruas jalan & 0.146 & -0.113 & $\mathbf{0 . 8 5 6}$ \\
\hline
\end{tabular}

Sumber: Data Diolah (2015)

Berdasarkan Tabel 4 faktor-faktor terbentuk yang mempengaruhi kesesuaian penggunaan lahan terhadap Rencana Pola Ruang dapat dijelaskan sebagai berikut:

Faktor 1 : Ketersediaan dan Kemudahan Mendapatkan Layanan, terdiri atas variabel Luas Wilayah, Jumlah Penduduk, Kepadatan Penduduk, Jarak ke Pusat Kecamatan, Jarak ke Pusat Kota, Rasio Keluarga Pertanian, Rasio Keluarga Pra Sejahtera, Rasio Luas Pertanian Lahan Kering, Jarak ke Pusat Perdagangan Terdekat, Jarak Ke Pusat Pelayanan Pendidikan Terdekat, Jarak ke Pusat Pelayanan Kesehatan Terdekat. Adapun keterkaitan dari masing-masing variabel dapat dijelaskan bahwa semakin luas wilayah maka jumlah dan kepadatan penduduk akan semakin mengecil. Luasan wilayah mempengaruhi terhadap jarak pencapaian ke daerah pusat, semakin besar wilayah maka semakin jauh jarak ke daerah pusat baik itu pusat kecamatan maupun pusat ke kota. Semakin jauh jarak ke pusat kota maka jarak pencapaian ke pusat-pusat layanan (perdagangan, pendidikan, dan kesehatan) pun semakin jauh, karena pusat-pusat layanan berada pada wilayah pusat baik 
itu pusat kecamatan maupun pusat kota. Besarnya wilayah mempengaruhi bentuk penggunaan lahan dimana wilayah yang memiliki luasan yang besar, tutupan/penggunaan lahan untuk pertanian lahan kering semakin besar. Besarnya luasan tutupan / penggunaan lahan sebagai pertanian lahan kering disertai dengan banyaknya rasio keluarga pertanian dan keluarga pra sejahtera.

Faktor 2 : Peningkatan Kesejahteraan, variabel Rasio Luas Sawah dan Rasio Luas Sawah dengan Pengairan yang Diusahakan serta Rasio Keluarga Sejahtera III. Pertumbuhan luas sawah diikuti dengan luasan sawah dengan pengairan yang diusahakan. Peningkatan luas sawah dengan pengairan yang diusahakan meningkatkan jumlah produktivitas lahan sawah yang pada akhirnya meningkatkan kesejahteraan (khususnya kesejahteraan petani). Peningkatan kesejahteraan akan memacu perubahan pemanfaatan penggunaan lahan.

Faktor 3 : Aksesibilitas,variabel yang memiliki korelasi kuat terhadap faktor 3 ini adalah variabel Pertumbuhan Ruas Jalan dan Laju Pertumbuhan Ruas Jalan. Peningkatan aksesibilitas dengan bertambahnya ruas-ruas jalan memudahkan masyarakat untuk membuka lahan, yang pada akhirnya menyebabkan alih fungsi lahan dapat mudah terjadi.

Untuk melihat seberapa kuat faktor yang yang terbentuk mempengaruhi kesesuaian penggunaan lahan dilakukan analisis regresi. Berdasarkan hasil analisis regresi (Tabel 5) bahwa ketiga faktor yang terbentuk dari hasil analisis faktor memiliki pengaruh yang nyata dan signifikan kepada kesesuaian penggunaan lahan tahun 2015 terhadap Rencana Pola Ruang RTRW Kota Baubau Tahun 2011-2031.

Berdasarkan hasil analisis regresi, model yang dibangun cukup baik untuk menjelaskan faktor-faktor yang mempengaruhi kesesuaian penggunaan lahan. hal ini ditunjukan dengan nilai $\mathrm{R}^{2}$ (0.479) yang bermakna bahwa variabel bebas mampu menerangkan $47,90 \%$ variabel terikat sedangkan sisanya dijelaskan oleh variabel lain yang tidak dimasukan dalam model penelitian ini. Faktor-faktor yang mempengaruhi kesesuaian penggunaan lahan yang menjadi variabel bebas dalam model regresi ini menunjukan bahwa ketiganya memiliki pengaruh yang nyata terhadap kesesuaian penggunaan lahan. Hal ini ditunjukan dengan hasil nilai signifikansi uji yang memiliki nilai lebih kecil dari nilai signifikansi penelitian yang ditetapkan (0.05)

Tabel 5 Hasil Analisis Regresi Faktor yang Mempengaruhi Kesesuaian Penggunaan Lahan di Kota Baubau $R=0.692 ; R^{2}=0.479 ;$ Adjusted $R^{2}=0.433 ;$ Std. Error of the Estimate $=0.7532$

\begin{tabular}{llccccc}
\hline \multirow{2}{*}{ Model } & & \multicolumn{2}{c}{$\begin{array}{c}\text { Unstandardized } \\
\text { Coefficients }\end{array}$} & $\begin{array}{c}\text { Standardized } \\
\text { Coefficients }\end{array}$ & $\mathrm{t}$ & Sig. \\
\cline { 3 - 7 } & & B & Std. Error & Beta & & \\
\hline $1 \quad \begin{array}{l}\text { (Constant) } \\
\text { Kemudahan Pencapaian Pusat-Pusat }\end{array}$ & $3.848 \mathrm{E}-17$ & 0.122 & & 0.000 & 1.000 \\
& Layanan & 0.425 & 0.124 & 0.425 & 3.429 & 0.002 \\
& $\begin{array}{l}\text { Peningkatan Kesejahteraan } \\
\text { Aksesibilitas }\end{array}$ & 0.477 & 0.124 & 0.477 & 3.855 & 0.000 \\
& 0.266 & 0.124 & 0.266 & 2.147 & 0.039 \\
\hline
\end{tabular}

Dependent Variable: Luas Penyimpangan Penggunaan Lahan

Sumber: Data Diolah (2015)

\section{KESIMPULAN}

Berdasarkan hasil evaluasi pemanfaatan penggunaan lahan, maka tingkat kesesuaian penggunaan lahan Kota Baubau tahun 2015 terhadap Rencana Pola Ruang berada pada kategori tingkat kesesuaian sedang. Berdasarkan hasil temuan dan analisis 
terdapat tiga bentuk inkonsistensi dalam Rencana Pola Ruang Kota Baubau. Adapun ketiga bentuk inkonsistensi tersebut adalah (1) inkonsistensi didalam perencanan Pola Ruang, (2) Rencana Pola Ruang inkonsistensi terhadap aturan dan peraturan perundang-undangan yang berlaku (3) inkonsistensi pemanfaatan penggunaan lahan terhadap Rencana Pola Ruang.

Adapun faktor yang mempengaruhi kesesuaian penggunaan lahan di Kota Baubau antara lain meliputi (1) Kemudahan mencapai pusat-pusat layanan, (2) Peningkatan kesejahteraan, dan (3) Aksesibilitas.

Berdasarkan hasil analisis maka diperlukan adanya peninjauan kembali dan revisi terhadap Rencana Pola Ruang RTRW Kota Baubau Tahun 2011-2031. Selain itu, didalam proses penyusunan Rencana Pola Ruang haruslah konsisten/taat asas kepada peraturan dan perundang-undangan yang berlaku.

\section{UCAPAN TERIMA KASIH}

Ucapan terima kasih kami sampaikan kepada Direktorat Jenderal Pendidikan Tinggi Kementerian Pendidikan dan Kebudayaan yang telah memberikan beasiswa pendidikan pascasarjana dalam negeri (BPPDN).

\section{DAFTAR PUSTAKA}

Adiningsih, E. S., \& Mahmud, E. I. (2004). Aplikasi analisis komponen utama dalam pemodelan penduga lengas tanah dengan data satelit multispektral. Jurnal Matematika Dan Sains, 9(1), 215-222.

Arsyad, S. (2006). Konservasi Tanah dan Air. Bogor: IPB Press.

Badan Standardisasi Nasional. (2002). SNI 19-6728.3-2002 tentang Penyusunan Neraca Sumberdaya - Bagian 3: Sumberdaya Lahan Spasial. Jakartal: Badan Standardisasi Nasional.

Dardak, A. (2005). Pemanfaatan lahan berbasis rencana tata ruang sebagai upaya perwujudan ruang hidup yang nyaman, produktif, dan berkelanjutan. In Seminar Nasional "Save Our Land for the Better Environments. "Bogor: IPB.

Ditjen Penataan Ruang Kementerian PU. (2010). Pedoman pemantauan dan evaluasi pemanfaatan ruang wilayah kota berbasis sistem informasi geografis. Jakarta: Ditjen Penataan Ruang Kementerian PU.

Faizu, W. (2011). Alternatif kebijakan pengelolaan Pantai Kamali hasil reklamasi di Kota Baubau yang meminimumkan dampak lingkungan. Institut Pertanian Bogor.

Gujarati, D. N. (2006). Ekonometrika Dasar. Jakarta: Erlangga.

Handayani, D., Soelistijasi, S., \& Sunardi. (2005). Pemanfaatan analisis spasial untuk pengolahan data spasial sistem informasi geografis, studi kasus Kabupaten Pemalang. Jurnal Teknologi Informasi Dinamik, 10(2), 108-116.

Lahamendu, V., \& Kustiwan, I. (2014). Evaluasi pemanfaatan lahan berbasis rencana tata ruang wilayah di Pulau Bunaken, Manado. Jurnal Perencanaan Wilayah Dan Kota, 2(3), 809-814.

Prahasta, E. (2002). Konsep-konsep Dasar Sistem Informasi Geografi. Bandung: Informatika Bandung.

Santoso, S. (2006). Seri Solusi Bisnis Berbasis TI: Menggunakan SPSS untuk Statistik Multivariat. Jakarta: Elex Media Komputindo.

Sekretariat Negara. UURI No. 13 Tahun 2001 tentang Pembentukan Kota Baubau (2001).

Sekretariat Negara. UURI No. 26 Tahun 2007 tentang Penataan Ruang (2007).

Sekretariat Negara. UURI No. 41 Tahun 2009 tentang Perlindungan Lahan Pertanian Pangan Berkelanjutan (2009).

Winarso, H. (1995). Tarif izin perubahan guna lahan perkotaan sebagai bentuk control pelaksanaan penataan ruang kota. Jurnal PWK, 172), 30-39. 